\title{
NMT1 wt Allele
}

National Cancer Institute

\section{Source}

National Cancer Institute. NMT1 wt Allele. NCI Thesaurus. Code C158396.

Human NMT 1 wild-type allele is located in the vicinity of $17 q 21.31$ and is approximately $57 \mathrm{~kb}$ in length. This allele, which encodes glycylpeptide $\mathrm{N}$-tetradecanoyltransferase 1 protein, plays a role in protein myristoylation. 